\title{
Ukrainian Migrants in the European Union: a Comparative Study of the Czech Republic and Italy
}

\section{Elena Ambrosetti}

Universita Roma Sapienza, Faculty of Economics, Department MEMOTEF, Roma, Italy

\section{Eralba Cela}

Universita Politechnica delle Marche, Department of Economics, Ancona, Italy

\section{Wadim Strielkowski**}

University of Economics, Faculty of International Relations, Department of Tourism, Prague, Czech Republic

e-mail: wadim.strielkowski@vse.cz

\section{Josef Abrhám}

University of Economics, Faculty of International Relations, Department of Tourism, Prague, Czech Republic

ABSTRACT This paper aims to provide a comparative analysis of links between personal characteristics and remittance behavior as well as to investigate the determinants of integration and to validate the remittance decay hypothesis in the target country for Ukrainian migrants in the Czech Republic and Italy. Our research attempts to answer a number of novel research questions by determining whether some personal attributes could be attached to Ukrainian labor migrants in the EU and their families in Ukraine. Our findings show that migration characteristics of one ethnic group or nation reveal the same patterns regardless of the target country. It appears that remittance behav-

\footnotetext{
** Corresponding author
} 
ior of Ukrainian migrants in the Czech Republic and Italy is significantly determined by their financial situation, demographic characteristics, level of human capital and level of integration as well as specific context characteristics. Moreover, our findings provide evidence for the fact that those Ukrainian migrants who are more settled in a target country tend to send fewer or no remittances back to their home country.

Key words: international migration, labour market, the Czech Republic, Ukraine, remittances.

\section{Introduction}

According to the economic theory, the welfare effect of immigration in the emigrantreceiving countries depends on the characteristics of the migrants, as well as on the domestic labor market conditions. In this context, the ethnic background and the origin of the migrants gain special importance, since some people (e.g. Roma) are pre-determined to migration more than others (see e.g. Šlezak, 2013). If high-skilled native workers are complementary inputs to low-skilled immigrants, then migrants positively affect labor productivity, economic growth and real wages in the target regions or countries - this process often happens in rural areas where farmers and farm labor migrates for work in agriculture (see e.g. Šarović, 2012). Longhi, Nijkamp and Poot (2005) examine 18 studies dealing with the effect of migration on wages and point out that results vary across countries and that they are related to the modelling approach. Negative or very small effects are found in studies dealing with migration wage response in Austria, Germany and UK (see e.g. Zimmermann and Winter-Ebmer, 1998; or Lemos and Portes, 2008), while the study conducted in Poland found that the Gini coefficient and migration are positively correlated (Stark et al., 2009). The recent economic crisis further deepened the welfare effect of migration and impacted on migrants' wages (see e.g. Signorelli et al., 2012).

Immigrants may choose their destinations according to the ability of absorb the additional labor supply they are about to provide. Quite often, inter-urban migration could offset adverse effects of immigration. Since migrants might also go after higher wage, the impact on wages and employment in the target countries may be underestimated (e.g. Card 1990, 1991 or World Bank 2006). The results may also depend on the selected econometric techniques (the reason why only weak impacts are typically found in the literature might be due to the application of cross-sectional data models, while panel data models often bring different results (World Bank, 2006)).

One of the most noticeable effects of migration on the source country is represented by remittances. Remittances typically constitute enormous inflows of money for receiving countries that is crucial for their development (see e.g. Deneulin, 2006 or Bettin et al., 2012). In 2010 alone, remittance flows were estimated to be at USD 440 billion, from which amount USD 325 billion was received by developing countries. As remittances often flow via informal channels, the amount could be much larger than remittances that are officially registered. 
Remittances are defined as transfers of money (or in kind transfers) that migrants send back to the country of their origin directly to families they left behind. Remittances usually amount into enormous inflows of foreign money for receiving countries. Just in 2010, remittance flows are estimated to more than USD 440 billion, from which amount USD 325 billion is received by developing countries. As remittances often flow via informal channels (see further in this section), the amount could be much bigger than remittances officially registered. Top recipient countries in 2010 were India, China, Mexico, the Philippines and France. Probably more striking statistics of remittances is their share on GDP, reaching enormous values in developing countries. Top recipients in this category in 2009 were Tajikistan (35\%), Tonga (28\%), Lesotho (25\%), Moldova (31\%), and Nepal (23\%). Among the countries that are source of remittances there are mainly US, Saudi Arabia, Switzerland and Russia (World Bank, 2011).

According to De Haas (2011), remittances have overtaken the amount of ODA provided to low and middle income countries. Figure 3 that follows shows the trend of remittances and official ODA to low and middle-income countries. From USD 23.5 billion in 1990, ODA decreased to USD 17.5 billion in 2000 and reached USD 42.4 billion in 2008 , while in the same time remittances to low and middle-income countries constituted USD 16.2 billion in 1990, reached USD 39.5 billion in 2000 and USD 161 billion in 2008.

Figure 1

Remittances and official ODA, lower and middle income countries (1970-2009)

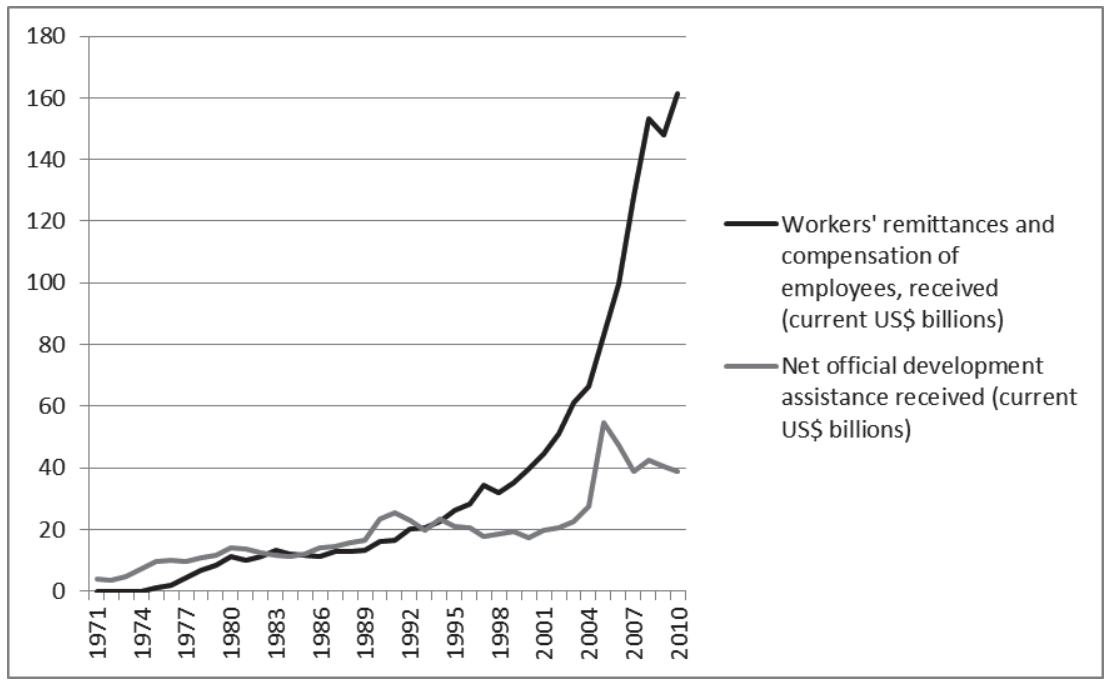

Source: World Development Indicators database, World Bank (2012).

Even in the time of financial turbulences when most of these flows tend to be volatile, remittances showed stability and seem to be less affected by economic cycles than private capital. For instance, during Asian financial crisis in 1998 - 2001 remit- 
tances even rose compared to the private capital (Ratha, 2005). As a response to the last financial and economic crisis, remittances fell by $5.5 \%$ in 2009 , contrasting to $40 \%$ decline of FDI, and they recovered quickly in 2010 (World Bank, 2011). Remittances are also further expected to rise in the long-term (Ratha, 2005). In the case remittances are counter-cyclical, they could serve as a policy tool to stabilize adverse effect of economic downturn. The relationship is dynamic, it changes over time and it depends on the conditions of the target country (Vargas-Silva, 2011).

Remittances became important within a theoretical framework only with the New Economics of Labour migration (Stark and Bloom, 1985; Taylor, 1999). By contrast in the first theory, that attempt to explain migration, the neo-classical one (Harris and Todaro, 1970; Sjaastad, 1962; Todaro, 1969), migration was considered as an individual income maximizing strategy, due to geographical differences in the supply and demand for labor and remittances did not found a justification (see e.g. De Haas, 2010).

The debate on remittances was triggered by Lucas and Stark (1985) with their study on Botswana. They individuated taxonomy of motivations in determining remittance behaviour: pure altruism, pure self-interest and an intermediate motive called "tempered altruism/enlightened self-interest.

Our paper takes of all the above into account and attempts to show what determinants influence the remittance transfers by Ukrainian migrants in the Czech Republic and Italy. Our paper provides a comparative analysis of links between personal characteristics and remittance behavior and outlines the main determinants of integration in the target country for Ukrainian migrants in the Czech Republic and Italy and is based on two unique surveys independently conducted in both countries. The analysis is based on two unique datasets provided by the Ukrainian Migration Project (2010-2012) conducted by the Charles University in Prague in the Czech Republic and INTEGROMETRO project (2008-2009) conducted by Italian researchers.

The paper is organized as follows: Part 2 provides a brief overview of the Ukrainian migration experience after the fall of Communism. Part 3 describes the data collection and both surveys conducted in the Czech Republic and Italy, part 4 introduces research methodology. Part 5 presents an empirical model and discusses its results. Part 6 provides conclusions and policy implications.

\section{Brief overview of the Ukrainian migration after the fall of Soviet Union}

Ukraine is a transition economy that still experiences economic and social turmoil after the collapse of the Soviet Union. The unemployment in Ukraine is high and the development is slow. In addition, there are various political and socio-economic problems such as dependency of Russian energy resources, "The Great Divide" between Russian-speaking East Ukraine and Ukrainian-speaking West Ukraine, ongoing fight for power dominated by the pro-Western opposition which culminated by the so-called "Orange revolution" and recent events (so-called "Euromaidan" protests) that turned Ukraine back to the EU. 
In the second half of the 1990s, Ukrainian factories decreased production, payments of wages were postponed and unemployment reached around 40\% if one included unrecorded numbers stemming from hidden unemployment (official statistics stated around 12\%). All these factors and low wages for those who were lucky enough to have a job created a set of push factors that support the trend of outmigration (Lupták, 2008).

For the whole decade the GDP growth was negative and economy started to recover in the beginning of the new century. That did not automatically mean that the recovery completely helped the soundness of economy. The GDP of the country in 2006 resulted in 63\% and in 2007 in 68\% of 1989's level. The world economic crisis caused further shock for the economy when in 2009 GDP shrank by 15\% (Kowalski and Polowczyk, 2012).

Figure 2

GDP per capita, current prices, USD

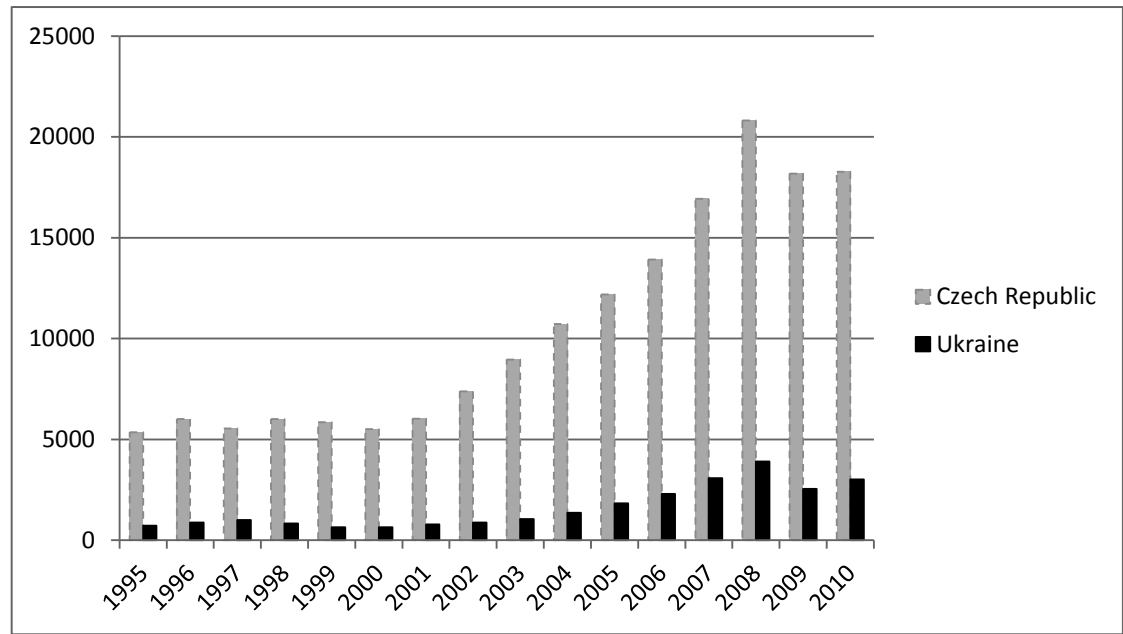

Source: International Monetary Fund, World Economic Outlook Database, September 2011

The evolvement of GDP per capita is depicted in Figure 2. The situation in Ukraine is clearly becoming better in the beginning of $21^{\text {st }}$ century. For the comparison, the situation in the Czech Republic is provided to the picture. The striking difference between values of GDP per capita is one of the evidence of better standards of living in the Czech Republic and thus these values can be understood as important motivation for Ukrainian migrant workers in the time of their choice of destination country.

Figure 3 shows the evolvement of GDP growth in both countries. In 1996 for the first time, GDP started to grow (growth exceeded zero level). Until 2006 the economy of Ukraine experienced fast growth reaching two digit numbers. The maximum was achieved in 2003, when the growth was over 15\%. The world financial crisis hit the economy greatly and caused almost 15\% declined of GDP. Again for the purpose 
of comparison, the evolvement of Czech economic performance is depicted in the Figure 3 .

Figure 3

GDP growth - a comparison of the Czech Republic and Ukraine (1995-2010)

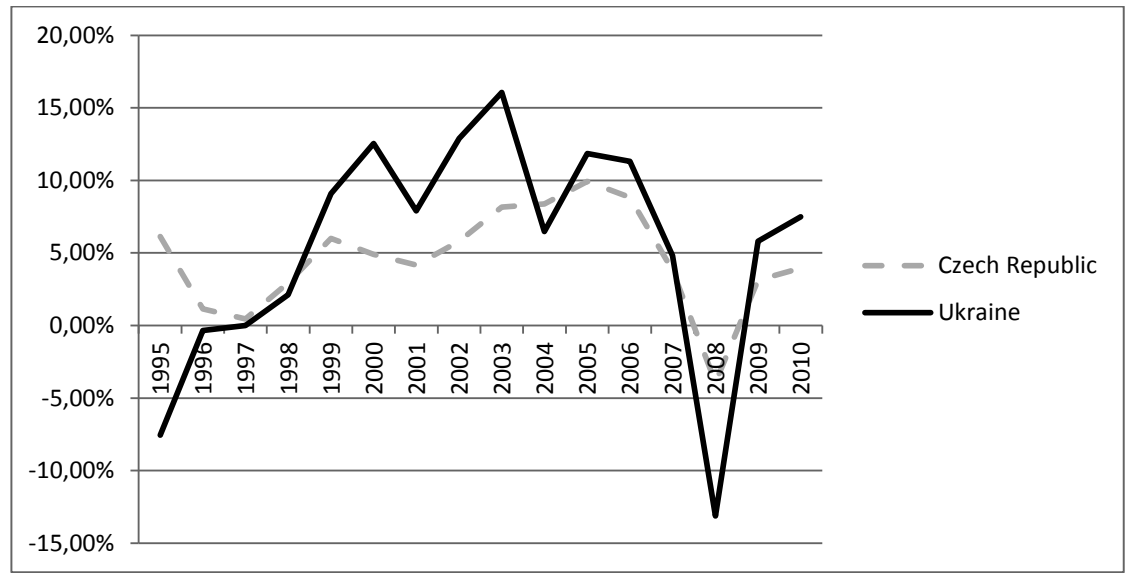

Source: International Monetary Fund, World Economic Outlook Database, September 2011

\subsection{Ukrainian migration in the EU and beyond}

After the collapse of the Soviet Union, the process of transformation cooperation and the overall orientation to Western Europe formed the new relationship and triggered migration movement from Ukraine to the West (Malynovska 2008, Düvell, 2006). There was also change in the type of migration - people did not migrate from ethic and political reasons, but mainly from economical (Jelínková et al 2011). Ukraine became very important supply of labour for Member states of the EU since more than half of migrants enter EU's labour markets (Siar et al. 2008, Malynovska 2008) and to keep pace with other countries, Ukraine had to adopt modern migration legislation, create migration and take part on cooperation in the sphere of migration (Malynovska 2008).

Ukrainian migration is typically circular (i.e. with intention to return back regularly or for good), $80 \%$ of emigrants long to come back to Ukraine eventually, they maintain relationships with families, stay in direct contact, quite often are able to come home and they also realize investments in Ukraine (Markov et al., 2009).

Currently more than $10 \%$ of Ukrainian population (1/5 of working age population) work abroad, typically on temporary basis (Düvell, 2006). According to Siar et al (2009) $15.7 \%$ of households has at least one or more members with experience of working abroad. Most often Ukrainians are engaged in secondary labour market and usually they do not constitute competitive counterparts to local workers (Markov et al. 2009). They are usually working in building and construction sector, in housekeeping and agricultural industry (Vollmer et al 2010). 
Despite the main importance of Ukraine as the source country of migrants for the Czech labour market, the Czech Republic, although no doubt an important target country for Ukrainian migrants, is not the most favourite. The Russian federation is the most linked country to Ukraine as a consequence of common history and still the majority of migrants leave Ukraine to settle down in Russia. Further, Ukrainians prefer to migrate to the Poland, USA, Israel, Kazachstan, Israel, Germany, Moldova, Belarus, Spain or Canada (WB 2011).

Another important aspect of labour migration for all developing countries is represented by remittances. Despite the fact that as a share of GDP, Ukraine is not among countries with highest levels (Ukraine received around 4\% of its GDP in 2010 (WB databank 2012), overall amount of remittances received is increasing substantially, as it is evident from Figure 4.

Figure 4

Remittances received, Ukraine, current USD

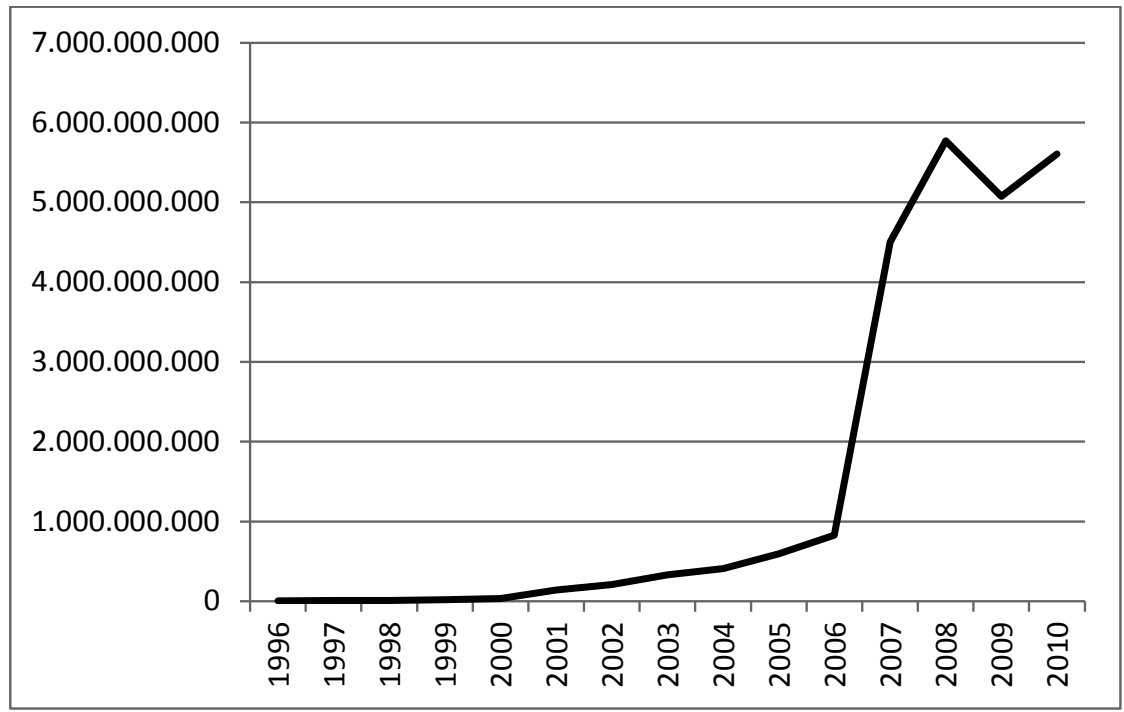

Source: WB databank 2012

From the pattern of the flow one can see that financial crisis affected the amount of remittances received, but the effect was not that severe, compared to the level of foreign direct investment, that shrink twice in the year of 2009 (World Bank databank, 2012).

It is necessary to understand that as remittances are surely sent via informal channels in a large extent (as it was mentioned above), the official amount of remittances is probably underestimated. For instance Markov et al (2009) in his research found out that as a share of Ukrainian GNP, international remittances (received by Ukraine) comprise $20 \%$. 
Due to all these issues, the outward migration from Ukraine remains at its highest level. In 2005 alone, the stock of emigrants originating from Ukraine was over 6 million people (World Bank, 2007) - this was 13.1\% of the whole population. The top 10 destination countries for Ukrainian migrants are: Russia, U.S., Poland, Israel, Kazakhstan, Moldova, Germany, Belarus, Spain and Canada. Currently, 14.7\% of total Ukrainian population lives abroad, mostly in post-Soviet states, Poland, United Kingdom, Czech Republic, Portugal, and Italy. Although the Czech Republic does not appear in top 10 destinations for Ukrainian outward migrations, the Ukrainian migrants constitute the highest share of all migrants in the country (according to the Czech Statistical Office, in 2010 alone the there were 128.636 Ukrainian nationals in the Czech Republic (30\% of all migrants) making the Ukrainians No. 1 foreign ethnic in this country) and Ukraine is undoubtly the most important source country of foreign labour for the Czech market (Czech Statistical Office, 2010).

The number of Ukrainians resident in Italy has steadily increased during the last decade passing from 12,000 in 2002 to 200,000 in 2010. Ukrainians are now ranked 5 among migrants resident in Italy. We need to stress also that Ukrainians resident in Italy are mostly women ( 3 out of 4 ) working in the care for elderly sector.

Determinants of emigration from Ukraine represent an interesting research question, especially when countries such as Czech Republic and Italy with the highest share of Ukrainian migrants are concerned. It appears interesting to find out whether some personal attributes leading to this migration can be determined. Further, it seems intriguing to understand the dynamics of this migration and to make predictions or extrapolations of possible future trends and changes in migration flows and stocks of Ukrainian migrations.

\section{Description of the data surveys conducted in the Czech Republic and Italy}

The relevance and importance of this paper mainly lies in the uniqueness and independence of the data set used for the estimations. Thanks to the availability of the first-hand data there is no need rely on the official and governmental sources that are often incomplete. Moreover, the issue of migration (including illegal migration) from Ukraine remains too sensitive and too difficult to capture by official statistics in the Czech Republic and Italy. Therefore, the UMP and Integrometro questionnaire surveys bring in novel data that are capable of providing new findings on the phenomenon of migration decisions and remittance behaviour in Ukraine, as the source country for migration, and the Czech Republic and Italy, as the target countries for migration.

\subsection{Ukrainian Migration project survey in the Czech Republic}

For the Czech Republic, the core data for this paper was obtained from three household surveys administered in Western Ukraine in 2010 and 2011 with 100 remittance- 
receiving households (359 respondents in total), 161 households (651 individuals in total) and 200 questionnaires in households having currently at least one member as a migrant in the Czech Republic and 50 questionnaires in households that currently do not have any family member residing abroad were held. All three surveys are a part of the Ukrainian Migration Project (UMP) that is on-going (2010-2012). The survey was conducted by the team of researchers from the Charles University in Prague in Western Ukraine, in particular Zakarpat'ye region, characteristic for its large share of emigrants in the local population and important is also the fact that in recent historyit came under authority of Austrian-Hungarian monarchy, Czechoslovakia, Hungary and the Soviet Union.

The survey focused on various socio-economic aspects of migration and its impacts. The research is divided into several tasks and many statistical methods are employed to collect data, such as semi structured in-depth interviews, diary records on daily incomes and spending of Ukrainian migrants in the Czech Republic and survey questionnaire both in Ukraine and in the Czech Republic.

Following methodology of Massey's MMP and LAMP, UMP questionnaires contained questions dealing with various economic and demographic characteristics, e.g.: household size, information on age, sex, education, occupation of each household member, total monthly net income of every household, percentage of income that is spent on food, the amount of remittances (both financial and in kind), that are received by the household from its members or non-members, frequency of receiving remittances. In addition, the questionnaire contained questions on the economic and social status of the migrant: her/his occupation, salary, marital status, attachment to family (expressed the frequency of contacting each other), knowledge of foreign languages.

All households in our sample were chosen by the stratified random sampling in urban, urban-rural and rural settlements in Zakarpat'ye region. At first, the research team randomly selected settlements for conducting interviews, and then the information from the 2001 Census was employed in order to select streets and households on the streets ( 3 households were selected on each street). The research team and the local associates then visited the locations and established whether the household residents had an emigrant in the Czech Republic who remitted (in case of the negative response, two other households to the left and to the right were visited). Only the families with migrants staying in the Czech Republic for more than a year (to exclude commuters or short-term migrants) and sending remittances were interviewed. The questionnaires were carried out either with the migrants him/herself (if she or her happened to be at home (e.g. on vacation, or for a brief visit) at a time of the interview, or with the adult family member (asking the interviewers to summon the most important head of the household (e.g. a father or mother), or another adult member of the household, etc.) who was aware of emigrant's whereabouts and her/ his economic and social situation. Thanks to this tactics the data obtained in the Czech part of the project were comparable to the data collected in the Italian part of the project Therefore, the data sample wasrobust enough (see e.g. Tahal 2013) to show the basic existing patterns and dependencies in migration from the Western Ukraine to the Czech Republic and in remittances flowing in the opposite direction. 


\subsection{Integrometroproject survey in Italy}

For Italy, data comes from the Integrometro survey (supported by the ISMU Foundation), a national wide survey on the specific topic of integration, carried out during October 2008 - February 2009. in about 32 provinces and towns across Italy, selected according the high incidence of migrants and their diversification in relation to the socio-economic context. Respondents were selected using the aggregation center sampling technique, (Blangiardo 1996), which is a suitable method for taking into account both legal and illegal migrants. This methodology had 2 steps: first mapping the places frequented by migrants from developing countries and then a random selection of the centers to carry out the interview: the assumption is that in each territory migrants are considered as a list of statistical units, that for living necessarily needs a number of contacts with some centers or "aggregation places", that can be official or unofficial (for example hospital, church, café, associations, malls, phone centers, etc), located in the territory, identified involving key community figures and other public and private stakeholders. In the second step migrants are selected random for the face to face interview. The problem of frequenting different centers had been avoided by assigning to each migrant a weight inversely proportional to the probability to be included in a center, taking into account the number of migrants that "usually" frequent that center.

The aim of the research was to understand the degree of migrants' integration in the Italian society (Cesareo and Blangiardo 2009). The questionnaire, besides the socio-demographic information focuses on four dimensions of integration identified in the survey as: cultural (language mastery, information sources both in Italy and origin country, sense of belonging), social (relationships, association participation, future projects, etc), economic (dwelling, working condition, economic condition) and political (citizenship, type of permits, relation with local authorities).

In all cities, an identical questionnaire was used, which made it possible to pool the data sets.The survey collected information on a total sample of 12,047 individuals aged between 18 and 71 years old, among 128 different nationalities from developing countries, with different religions and different types of migration, both in terms of socio-economic position and in terms of migration waves.

For the scope of this paper only data on Ukrainian migrants were selected (690 Ukrainians). In all areas, an identical questionnaire was used, which made it possible to pool the data sets. The survey focused on the lives of migrants with the purpose to measure the migrants' level of integration in its different aspects; economic, cultural, social and political. The questionnaire is composed of two sections. In the first one, the questions refer to the four dimensions of integration identified: cultural (knowledge and use of Italian language, interest in the Italian events, use of mass media), social (friendships, participation in association, level of satisfaction with Italian lifestyle), economic (income, employment, housing, perceived difficulties with income) and political (citizenship and opinion on the importance of citizenship for migrants and their children, legal status and registration with Registry Office). The 
second section encompasses socio-demographic characteristics and questions on remittances and the feeling of belonging to the home country.

\subsection{Descriptive statistics: Ukrainian migration in the Czech Republic}

The descriptive statistics for the Ukrainian migrants in the Czech Republic are summarized in Table 1. Firstly, migrants' characteristics are examined. Summary statistics of migrants are displayed in the following table. Almost four fifths (79.9\%) of migrants in the sample are male. The age of migrants varies from 19 to 64. Average age is 42.2 years. The vast majority (84.4\%) from the group of migrants is married. With regard to the level of education, the largest share was migrants with university degree $-55.2 \%$, and the second largest group was constituted by those migrants who completed secondary school - 41\%. $58.5 \%$ of migrants are able to speak "somewhat" Czech.

If analysing men and women separately, one finds that women are on average 38.7 years old, $62.8 \%$ of them have university degree and $32.6 \%$ completed secondary education. Almost 70\% from women are married. Men are on average older but the share of men with university degree is lower $52,6 \%$, and the share of those finished education on secondary level is $42.1 \%$. $87 \%$ of male migrants are married. The ability to speak Czech is almost the same for both women and men (Table 2).

Table 1

Summary statistics of Ukrainian migrants in the Czech Republic

\begin{tabular}{|l|c|c|}
\hline Statistic & Measure & Value \\
\hline Lifecycle characteristics & $\%$ & 79.9 \\
\hline Males & $\%$ & 20.1 \\
\hline Females & $\%$ & 84.4 \\
\hline Married & Mean & 42.2 \\
\hline Age & & \\
\hline Human capital & $\%$ & 55.2 \\
\hline University degree & $\%$ & 41.0 \\
\hline Secondary school & $\%$ & 58.5 \\
\hline Ability to speak Czech & $\%$ & \\
\hline Trip Characteristic & $\%$ & 51.9 \\
\hline Income group 3 & $\%$ & 43.2 \\
\hline Job in construction sector & $\%$ & 11.4 \\
\hline Job in manufacturing sector & & \\
\hline
\end{tabular}

Source: own estimations. 
Table 2

Comparison of statistics Male vs. Female

\begin{tabular}{|l|c|c|}
\hline Statistic & Male & Female \\
\hline Age & 43.1 & 38.7 \\
\hline Married & $87.1 \%$ & $69.8 \%$ \\
\hline Secondary school & $42.1 \%$ & $32.6 \%$ \\
\hline University degree & $52.6 \%$ & $62.8 \%$ \\
\hline Ability to speak Czech & $48.0 \%$ & $48.8 \%$ \\
\hline
\end{tabular}

Source: own estimations

Regarding the economic activity that Ukrainian immigrants are engaged in, Figure 5 depicts the situation. Particular economic activities were divided into primary, secondary and tertiary economic sectors. In order to highlight the how construction sector is important for Ukrainian labour migrants, it is taken away from secondary sector as separated category. Not less than 56\% of Ukrainian immigrants from the sample work in construction sector. Together with other economic activities from secondary economic sector it makes 68\%. Almost one quarter is working in tertiary sector.

Figure 5

Economic activity

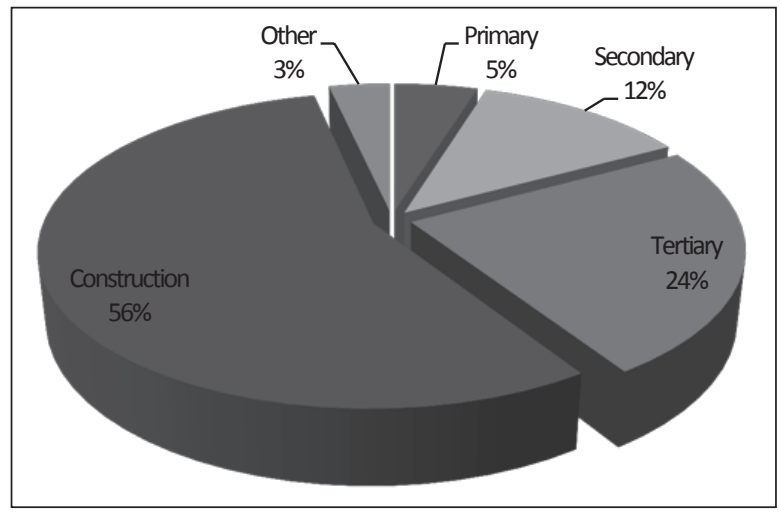

Source: own estimation

Regarding employment status of immigrants, the following pie chart (see Figure 6) reveals that almost the half of migrants is working temporarily. The second largest group of labour migrants is employed in the private sector - approximately one third. 
Figure 6

Employment status

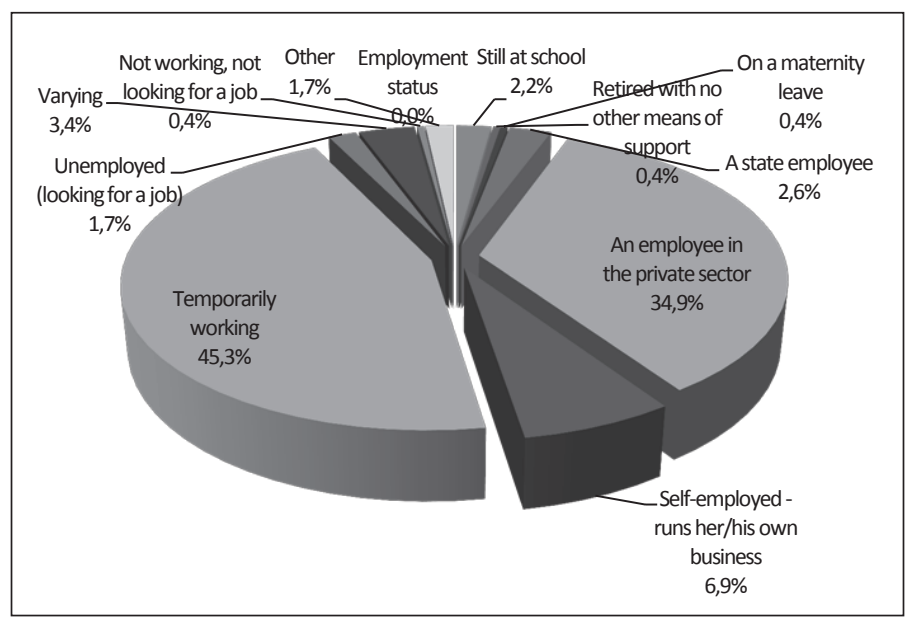

Source: own estimations

Table 3 shows comparison of 4 characteristics for households receiving remittances $($ Rem $=1)$ and households that do not receive remittances $($ Rem=0). Households that currently have member working in the Czech Republic and sending remittances have on average lower number of members and lower number of dependants. ${ }^{1}$ Furthermore, households receiving remittances spend slightly lower share of their income on food.

Income of the households is a categorical variable that has 6 categories. Out of 6 income groups, $63.3 \%$ of households receiving remittances belongs to the category 3 and 4 (middle categories), whereas only $26.6 \%$ from non-receivers belong to these two categories.

Table 3

Comparison of households with and without remittances

\begin{tabular}{|l|l|c|c|}
\hline Statistic & Measure & Value & Value \\
\hline & & Rem=1 & Rem=0 \\
\hline Household size & Mean & 2.92 & 4.3 \\
\hline Dependants & Mean & 1.90 & 2.6 \\
\hline Share of income spent on food & Mean & $39.4 \%$ & $41.4 \%$ \\
\hline Income group 3 and 4 & $\%$ & 63.3 & 26.6 \\
\hline
\end{tabular}

Source: own estimation

1 In thispaper, all household members that do not work are considered to be dependant (most often children, students and retired members belong to the group) 
The distribution of income among households is better pictured in following histogram, where frequencies are used to show that the family belongs to certain group. Interesting fact is that families that do not receive remittances are much more evenly distributed than families that do receive remittances.

Figure 7

Distribution of income

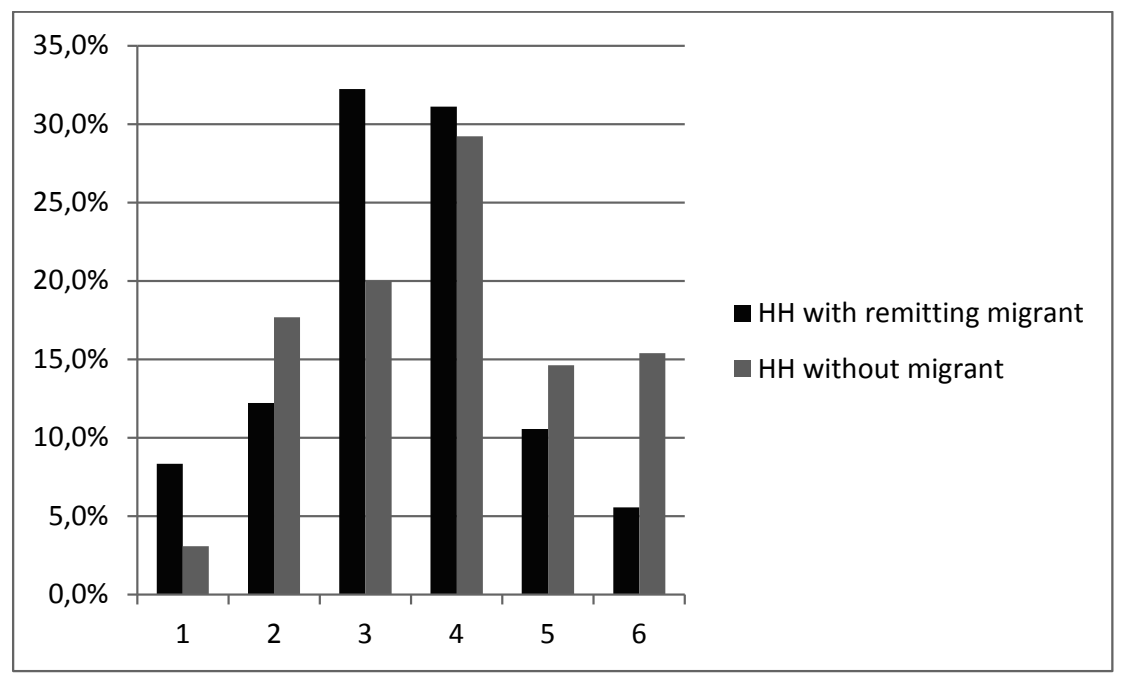

Source: own estimations

\subsection{Descriptive statistics: Ukrainian migration in Italy}

The descriptive statistics for the Ukrainian migrants in Italy is provided in the Tables 4-5 and Figures 8-11 that follow:

Table 4

Summary statistics of Ukrainian migrants in Italy

\begin{tabular}{|l|c|c|}
\hline Statistic & Measure & Value \\
\hline Lifecycle characteristics & & \\
\hline Males & $\%$ & 16.2 \\
\hline Females & $\%$ & 83.8 \\
\hline Married & $\%$ & 48.8 \\
\hline Age & & 42.2 \\
\hline Human capital & $\%$ & \\
\hline University degree & $\%$ & 35.4 \\
\hline Secondary school & $\%$ & 45.9 \\
\hline Ability to speak Italian & $\% 3$ \\
\hline
\end{tabular}




\begin{tabular}{|l|c|c|}
\hline Statistic & Measure & Value \\
\hline Trip Characteristic & & \\
\hline Job in the service to individuals/families & $\%$ & 68.5 \\
\hline Job in the commerce sector & $\%$ & 7.8 \\
\hline Monthly income (group 3) & $\%$ & 29.9 \\
\hline Send remittances & $\%$ & 86.3 \\
\hline
\end{tabular}

Source: own estimations.

Table 5

Comparison of statistics Male vs. Female

\begin{tabular}{|l|c|c|}
\hline Statistic & Male & Female \\
\hline Age (mean) & 36.4 & 43.5 \\
\hline Married & 56.2 & 47.4 \\
\hline Secondary school & 47.7 & 45.5 \\
\hline University degree & 25.7 & 37.3 \\
\hline Ability to speak Italian & 52 & 53 \\
\hline Send remittances & 77 & 88 \\
\hline
\end{tabular}

Source: own estimations

Figure 8

Economic activity of Ukrainian migrants in Italy

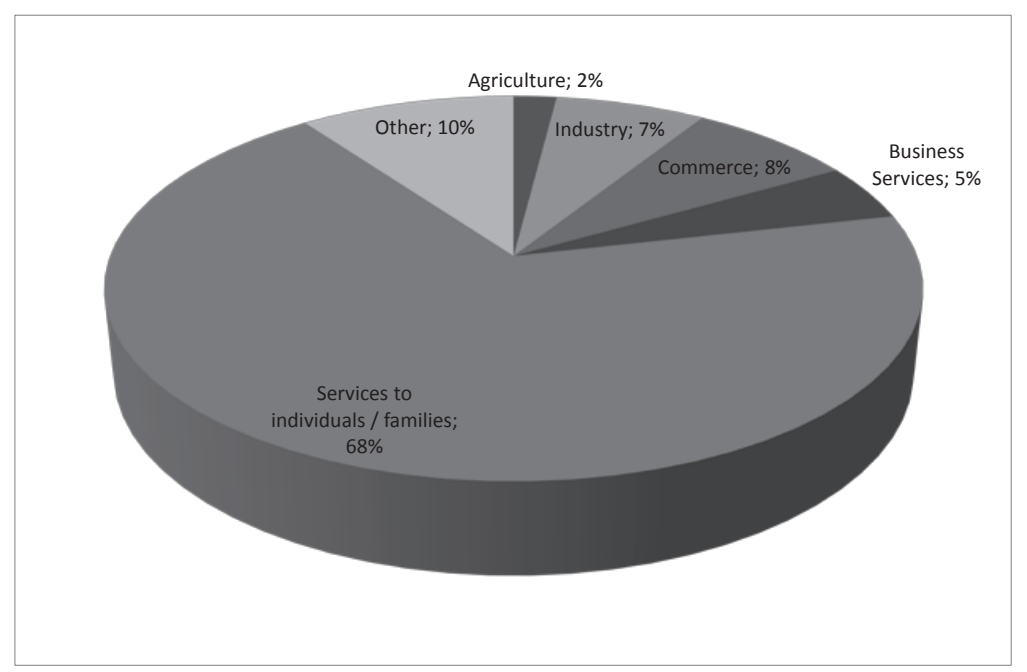

Source: own estimations. 
Figure 9

Employment status of Ukrainian migrants in Italy

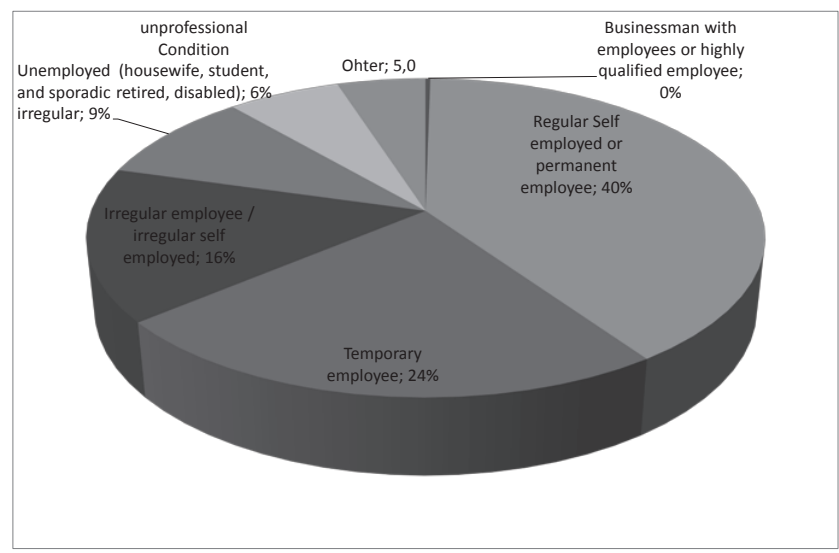

Source: own estimations.

Figure 10

Age Pyramid, Ukrainian Population resident in Italy, 1st of January 2011

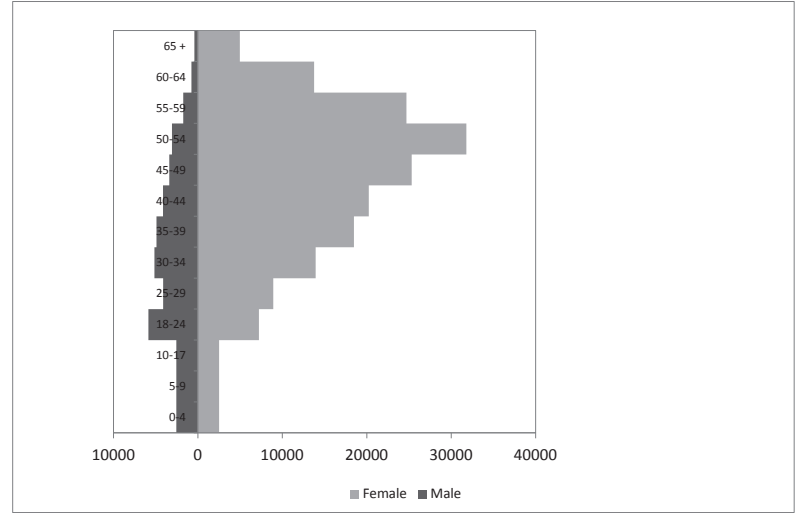

Source: own estimations on data from ISTAT: http://demo.istat.it/

Figure 11

Ukrainian Population in Italy (2003-2011)

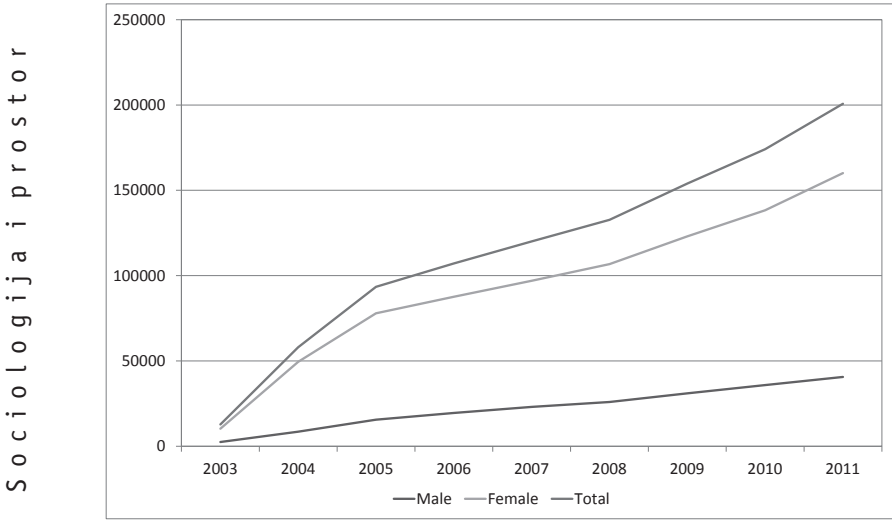

Source: own estimations on data from ISTAT: http://demo.istat.it/ 


\section{Research methodology and hypotheses}

In this study we compare remittances behaviour of migrants from the same country of origin: Ukraine, in two different migration contexts, Italy and Czech Republic. In doing so, we compare individual characteristics of migrants and their likelihood to remit. Individual characteristics include legal status, language proficiency and return intentions. Previous comparative studies on immigrants from a single country of origin have focused on their (socioeconomic) incorporation in the receiving country (Model and Ladipo 1996; Connor and Massey 2010; Kogan 2003; or Euwals et al. 2007). Thus, the main aim of those studies is to analyse the different structural and institutional characteristics of receiving countries.

Economic and social integration of migrants at the destination depends not only on their characteristics, but also on the characteristics of the receiving societies. Different migration policies such a selective migration process and differential treatment received by migrants may generate cross national differences. So as Model and Ladipo (1996) stressed, similar (or different) outcomes among migrants of the same origin in different receiving countries may depend on both similar (or different) pre-migration experience, and similar (or different) post-migration experience. The same hypothesis could be extended also to remittances. Thus, building on previous studies on migrants economic integration in different destination contexts and on migrants remittances literature (discussed above), we can formulate the following hypothesis on the remittances' behaviour of Ukrainian in Czech Republic and Italy.

Hypothesis 1: Remittance behaviour of Ukrainian migrants in the Czech Republic and Italy is significantly determined by their income, demographic characteristics, human capital and the level of integration as well as the specific context characteristics.

Hypothesis 2: Ukrainian migrants who are more settled in a target country will send less or no remittances back home to Ukraine.

Hypothesis 2 is the logical extension of the first hypothesis and seeks to introduce the level of integration of Ukrainian migrants in both Czech Republic and Italy into the formal analysis. Hypothesis 2 reflects the so-called "hypothesis of decaying remittances" that is based on Stark (1978). It turns out that remittances reach their peak shortly after the migrants settle in a new country and then slowly decline with occasional spikes in response to current needs and events in their country of origin (Stark, 1978). While testing hypothesis 2, Stark's hypothesis will be tested on our data sample of Ukrainian migrants residing in the Czech Republic and Italy, which will help us to shed some light on their integration patterns and remittances behavior.

Determinants of remittance behaviour (Hypothesis 1) will be tested using binary response models. In particular, Logit, Probit and Linear probability model (LPM) are applied, where the binary dependent variable is equal to 1 if the person remits and 0 otherwise. More detailed definition of variables employed in the model is provided in Table 6. 
The dependent variable is analysed in relation of a series of independent variables, some continuous other dummies, concerning four dimensions (see Table 6):

1) Immigrants' individual characteristics: age, gender and the marital status, the level of education attained. For education we expect a positive effect according to both the altruism and the self-interest theories (though a negative effect of education according to the exchange model).

2) Financial and labour situation: the household or personal income, the labour condition, problems in making end meets, and the ownership of a bank account. All those variables are directly related to the integration of migrants in the country of origin and to their likelihood to remit.

\section{Table 6}

Description of variables used in the model

\begin{tabular}{|c|c|c|}
\hline Dimensions & $\begin{array}{l}\text { Variables used in the } \\
\text { model }\end{array}$ & Description \\
\hline $\begin{array}{l}\text { Individual } \\
\text { characteristics }\end{array}$ & $\begin{array}{l}\text { Age } \\
\text { Marital status } \\
\text { Gender } \\
\text { Education }\end{array}$ & $\begin{array}{l}\text { Years of age } \\
\text { Categorical, } 1=(\text { single }), 2=(\text { married }), 3=(\text { widowed }), \\
4=(\text { divorced }), 5=(\mathrm{n} / \mathrm{a}) \\
\text { Categorical, } 1=(\text { male }), 2=(\text { female }) \\
\text { Categorical, } 1=(\text { no degree }), 2=(\text { primary }), 3=(\text { second- } \\
\text { ary), } 4=(\text { university }), 5=(\mathrm{n} / \mathrm{a})\end{array}$ \\
\hline $\begin{array}{l}\text { Financial and } \\
\text { labor situation }\end{array}$ & $\begin{array}{l}\text { Income } \\
\text { Problems to make end } \\
\text { meets } \\
\text { Employment status } \\
\text { Bank account in the } \\
\text { country }\end{array}$ & $\begin{array}{l}\text { Categorical, } 1=(\text { less than } 360 \text { EUR }), 2=(400-760 \\
\text { EUR), } 3=(800-1160 \text { EUR), } 4=(1200-1560 \text { EUR }), 5= \\
\text { (more than } 1600 \text { EUR) } \\
\text { Categorical, } 1=(\text { manage to save), } 2=(\text { spend all } \\
\text { earned), } 3=(\text { make ends meet) } \\
\text { Dummy, } 1=(\text { legally employed), } 2=(\text { otherwise) } \\
\text { Dummy, } 1=(\text { yes }), 0=(\text { no) }\end{array}$ \\
\hline $\begin{array}{l}\text { Settlement in } \\
\text { the country }\end{array}$ & $\begin{array}{l}\text { Citizenship of friends } \\
\text { Years of residence in the } \\
\text { country } \\
\text { Legal status } \\
\text { Language proficiency }\end{array}$ & $\begin{array}{l}\text { Categorical, } 1=(\text { only foreigners }), 2=\text { (more foreigners } \\
\text { than locals), } 3=\text { (both), } 4=\text { (more locals than foreigners) } \\
\text { Years of residence } \\
\text { Dummy, } 1=(\text { legal immigrants in the country, } 2=\text { (illegal } \\
\text { immigrant) } \\
\text { Dummy, } 1=(\text { know the language }), 0=\text { (otherwise) }\end{array}$ \\
\hline $\begin{array}{l}\text { Transnational } \\
\text { ties }\end{array}$ & $\begin{array}{l}\text { Return intentions } \\
\text { Children in Ukraine } \\
\text { Feeling of belonging to } \\
\text { Ukraine }\end{array}$ & $\begin{array}{l}\text { Categorical, } 1=(\text { forever }), 2=(\text { for long }), 3=(\text { for short } \\
\text { period) } \\
\text { Dummy, } 1=(\text { children }), 0=(\text { no children }) \\
\text { Categorical, } 1=(\text { very much }), 2=(\text { enough }), 3=(\text { little }), \\
4=(\text { not at all })\end{array}$ \\
\hline
\end{tabular}

Source: own compilation 
3) Settlement in the target country: Citizenship of friends: co-ethnic friendship may play an important role in the decision to send remittances. Years of residence: the longer the length of permanence the less the remittances provided. Legal status including permanent residence in destination country and naturalisation may of course largely contribute to integration in the country of origin and also imply intention of settlement of migrants (Euwals et al., 2007; or Kogan, 2003), illegal status may indeed lead to less economic integration (Connor and Massey, 2010; Massey and Brown 2011); Language proficiency: is an indicator of social, cultural and economic integration (Euwals et al., 2007).

4) Transnational ties: finally the last instruments are represented by the return intentions, the presence of children in Ukraine, and by emotional attachment to Ukraine.

It has to be mentioned that in analysis where binary responds methods are applied, results for Probit and LPM models are displayed for the purpose of comparison. The same signs of estimates and the level of significance support robustness of Logit estimates. However, statistical interpretation is only provided for Logit models since it is more straightforward than interpretation of results from Probit models. Besides, Logit estimates do not possess main drawbacks of LPM - linearity and unbounded dependent variable.

The dependent variable $\mathrm{Y}$ in probability model is dichotomous - the individual either remits some positive financial amount or not. Thus $y=1$ holds for Ukrainians who migrate and remit. Estimates of coefficients of explanatory variables $\beta$ show how much the odds of remitting is increased if the explanatory variable increase. Thanks to the control group of observations among families with no migrants there is a possibility to estimate effects of particular characteristics on the probability of migration and sending remittances on the individual level. One group consists of those who remit and the in the control group there are all members of all households in the productive age of $18-65$, students and retired excluded. By the introduction of binary variable that is equal to 1 if there is "Another member in the household who already remits", the fact, that there is already somebody else from the particular household remitting money from Italy or the Czech Republic, is captured.

The dependent variable is equal to 1 if the situation "positive amount of remittances sent" occurs. The choice of explanatory variables is inspired by the studies of Massey and Connor (2010), Massey, Durand, Pren (2011) and Massey and Brown (2011) that study migration and characteristics of migrants originating from the same country or region (e.g. Latin America, Mexico) and migrating to different target countries (e.g. USA vs. Canada, or USA vs. Spain).

In Logit model that is interpreted here, mostly the sign estimated coefficients are important but the magnitude reveals some information as well. Positive sign signals that, ceteris paribus, the odds of remittance occurrence are rising with increase in the explanatory variable. If one is interested in the magnitude, taking the value of exp of the estimate results in odds ratio, since coefficient actually are log odds ratios. 


\section{Empirical model results and discussions}

We run the analysis using the pooled sample of Ukrainian migrants from the Czech Republic and Italy. The Italian categorical variable was used to differentiate between Ukrainian migrants from Italy from their compatriots from the Czech Republic. The results of the estimations are presented in Table 7 that follows. Overall, it appears that remittance behaviour of Ukrainian migrants in both countries is in fact determined by some of their personal characteristics such as financial situation (problems to make ends meet), demographic characteristics (age, marital status, children), and the level of integration as well as the specific context characteristics (legal status or "belonging" to their country of origin).It appears that the more mature migrants who left their families at home are the most significant senders of remittances.

Table 7

Results of the empirical model of Ukrainian migrants in the Czech Republic and Italy

\begin{tabular}{|c|c|c|c|c|c|c|}
\hline & \multicolumn{2}{|c|}{ Logit } & \multicolumn{2}{|c|}{ Probit } & \multicolumn{2}{|c|}{$\begin{array}{c}\text { Linear Probability } \\
\text { Model }\end{array}$} \\
\hline & $\beta$ & SE ( $\beta)$ & $\beta$ & SE ( $\beta$ ) & $\beta$ & SE ( $\beta)$ \\
\hline \multicolumn{7}{|l|}{ Probability person remits } \\
\hline \multicolumn{7}{|l|}{ Independent variables } \\
\hline \multicolumn{7}{|l|}{ Individual characteristics } \\
\hline Age & $.2184^{* * * *}$ & .0658 & $.1256^{* * * *}$ & .0368 & $.0264^{* * * *}$ & .0093 \\
\hline Age squared & $-.0025^{* * * *}$ & .0008 & $-.0014^{* * * *}$ & .0004 & $-.0002^{* * * *}$ & .0001 \\
\hline Marital status & $.3581^{* * *}$ & .1809 & $.1948^{* * *}$ & .0921 & $.0227^{*}$ & .0126 \\
\hline Gender & .3593 & .4061 & .2198 & .2118 & .0393 & .0485 \\
\hline Education & -.0052 & .1925 & -.0303 & .1009 & .0010 & .0132 \\
\hline \multicolumn{7}{|l|}{ Financial and labour situation } \\
\hline Income & -.1573 & .2098 & -.0830 & .1065 & -.0109 & .0176 \\
\hline Problems to make ends meet & $-.4336^{* *}$ & .1931 & $-.2322^{* *}$ & .1028 & $-.0412^{* * *}$ & .0187 \\
\hline Employment status & -.3240 & .4680 & -.1438 & .2377 & -.0307 & .0491 \\
\hline Bank account & .1357 & .3531 & .0685 & .1806 & .0112 & .0275 \\
\hline \multicolumn{7}{|l|}{ Settlement in the country } \\
\hline Citizenship of friends & -.1096 & .1818 & -.0482 & .0926 & -.0058 & .0143 \\
\hline Year of residence & -.0202 & .0505 & -.0144 & .0250 & -.0028 & .0056 \\
\hline Legal status & $1.1350^{* * *}$ & .5155 & $.5721^{* *}$ & .2637 & $.1074^{* * *}$ & .0641 \\
\hline Language proficiency & .1221 & .6167 & .0524 & .3133 & .0093 & .0504 \\
\hline
\end{tabular}




\begin{tabular}{|c|c|c|c|c|c|c|}
\hline & \multicolumn{2}{|c|}{ Logit } & \multicolumn{2}{|c|}{ Probit } & \multicolumn{2}{|c|}{$\begin{array}{c}\text { Linear Probability } \\
\text { Model }\end{array}$} \\
\hline & $\beta$ & SE $(\beta)$ & $\beta$ & SE $(\beta)$ & $\beta$ & SE $(\beta)$ \\
\hline \multicolumn{7}{|l|}{ Probability person remits } \\
\hline \multicolumn{7}{|l|}{ Independent variables } \\
\hline \multicolumn{7}{|l|}{ Transnational ties } \\
\hline Return intentions & -.0120 & 1487 & -.0132 & .0776 & -.0013 & .0103 \\
\hline Children & $.8606^{* * *}$ & .3998 & $.4513^{* * *}$ & .2066 & $.0659^{* * *}$ & .0351 \\
\hline Children in Ukraine & $-.5605^{* * *}$ & .2782 & $-.2987^{* * *}$ & .1467 & -.0305 & .0192 \\
\hline Belonging to Ukraine & $-.4502^{* * *}$ & .1961 & $-.2310^{* * *}$ & .1060 & $-.0414^{* *}$ & .0207 \\
\hline Italian dummy & .3262 & .7420 & .1461 & .3714 & .0366 & .0793 \\
\hline Constant & -2.7687 & 2.0818 & -1.5080 & 1.1310 & .2463 & 2173 \\
\hline McFadden R-squared & 0.14 & & 0.15 & & & \\
\hline Pseudo LL & -165.028 & & -164.474 & & & \\
\hline Wald chi2 & $53.40^{* * * *}$ & & $54.5^{* * * *}$ & & & \\
\hline R-squared & & & & & 0.11 & \\
\hline Number of observations & 611 & & 611 & & 611 & \\
\hline
\end{tabular}

Note: * Significant on the $10 \%$ level;** Significant on the $5 \%$ level; *** Significant on the 1\% level Source: own results.

An interesting fact about legal status of Ukrainian migrants is that it appears to be significant for both countries and influences the fact whether the migrant sends remittances back home to Ukraine. This might be explained by the fact that those migrants who are more settled (enjoy the legal residence in the target country), feel more comfortable to send remittances (e.g. instead of trafficking cash back home). This might be due to the fact that most of the money transfer operators (MTOs) and banks require the sender to present a valid ID and an expired passport or visa might arose suspicions (or some most of the Ukrainian migrants might think).

Another interesting result is about the fact that while having children comes through as positive and significant for sending remittances, having those children in Ukraine reduces the probability that the migrants sends remittances. This might be attributed to the fact that in many cases children live with their parents abroad, or that most of the remittances are not sent to the children in Ukraine, but rather to parents, rela- 
tives and other family members.

Finally, the factor of "belonging to Ukraine" also seems to reduce the probability of sending remittances. This is an interesting result that might be explained by the fact that those migrants who feel less "attached" to their source country might also feel obliged to send remittances back home to those they left behind. These remittances might be perceived as their "indulgences" for leaving their home country (and probably never intending to come back).

\section{Conclusions and policy implications}

Our results demonstrate that remittance behaviour of Ukrainian migrants in the Czech Republic and Italy is significantly determined by their financial situation, demographic characteristics, level of human capital and the level of integration as well as the specific context characteristics. In this context, it can be shown that the legal status "having the right papers", feeling of "belonging" to Ukraine and the necessity to "make ends meet" influence both frequency and the amount of remittances sent back to Ukraine. Additionally, similar demographic and social characteristics (age, marital status, number of children) can be traced for both Ukrainians residing in the Czech Republic and in Italy. It is also worth noting that older migrants send more remittances back home, perhaps in an attempt to secure a decent standard of leaving for themselves after their planned return to Ukraine as pensioners.

We also find the evidence for the fact that Ukrainian migrants who are more settled in a target country will send less or no remittances back home to Ukraine. This finding supports the hypothesis of decaying remittances that often comes through as significant in case of many countries and groups of migrants.

The data obtained with the help of both surveys was confronted with the main findings from migration theories and research literature on migration and remittances. The importance of approach used in our study relied on the independent data set which enabled us to test the main hypotheses without using official sources and governmental data that cannot capture all important facts and figures of this topic. Therefore, our results are of a special interest, since they represent an interesting insight into the characteristics of Ukrainian Diaspora in the EU countries (represented both by the "old" and the "new" EU Members States).

The outcomes of our study might enrich the knowledge on migration and remittances from the perspective of basic and applied research in the Czech Republic and Italy with the implications for the whole EU, especially in the light of the recent political development in Ukraine that might have an effect on outward Ukrainian migration to the EU countries. 


\section{Bibliography}

1. Bettin, G.; Lucchetti, R. and Zazzaro, A. (2012). Financial development and remittances: Micro-econometric evidence. Economic Letters, 115 (2): 184-186.

2. Blangiardo, G. C. (1996). Il campionamento per centri o ambienti di aggregazione nelle indagini sulla presenza straniera, in: Atti in onore di G. Landenna. Milano: Giuffré: 14-30.

3. Card, D. (1990). The Impact of the Mariel Boatlift on the Miami Labor Market. Industrial and Labor Relations Review, 43 (2): 245-257.

4. Card, D. (2001). Immigrant Inflows, Native Outflows, and the Local Market Impacts of Higher Immigration. Journal of Labor Economics, 19 (1): 22-64.

5. Cesareo V.; Blangiardo G. C. (2009). Indici di integrazione, Collana Ismu, Milano, Franco Angeli.

6. Connor, P. and Massey, D. S. (2011). Labor Market Insertion among Latino Migrants to Spain and the United States. Differences by source country and legal status. Revista Internacional de Sociologia, 69 (1): 189-218.

7. Czech Statistical Office (2010). Počet cizinc $v \check{C R}$ (Number of foreigners in the Czech Republic). Retrieved from: http://www.czso.cz/csu/cizinci.nsf/kapitola/ ciz_pocet cizincu.

8. De Haas, H. (2010). Migration and development: a theoretical perspective. International Migration Review, 44 (1): 227-264.

9. De Haas, H. (2011). The migration and development pendulum: A critical view of research and policy. Paper presented at International Conference "The Migration-Development Nexus Revisited: State of the Art and Ways Ahead", University of Trento, June.

10. Deneulin, S. (2006). Individual Well-being, Migration Remittances and the Common Good. The European Journal of Development Research, 18: 45-58.

11. Düvel, F. (2007). Ukraine - Europe's Mexico? Central and East European migration. Country report 1. Oxford: Centre of Migration, Policy and Society.

12. Durand J.; Kandel, W.; Parrado, E. A.; Massey, D. S. (1996). International migration and development in Mexican communities. Demography, 33 (2): 249-264.

13. Durand J. and Massey, D. S. (1992). Beyond Smoke and Mirrors: Mexican Immigration in an Age of Economic Integration. New York: Russell Sage Foundation.

14. Euwals, R.; Dagevos, J.; Gijsberts, M.; Roodenburg, H. (2007). The labour market position of Turkish immigrants in Germany and the Netherlands: Reason for migration, naturalisation and language proficiency. IZA Discussion Paper No. 2683, IZA Bonn.

15. Funkhouser, E. (1992). Mass emigration, remittances and economic adjustment: The case of El Salvador in the 1980s, in: G. Borjas and R. Freeman (eds.). Migration and the Workforce: Economic Consequences for the United States. Chicago, IL: University of Chicago Press.

16. Harris, J. R. and Todaro, M. P. (1970). Migration, Unemployment and Development: A Two Sector Analysis. American Economic Review, 60 (1): 120-142.

17. Kogan, I. (2003). Ex-Yugoslavs in the Austrian and Swedish labor markets: the significance of the period of migration and the effect of citizenship acquisition. Journal of Ethnical and Migration Studies, 29 (4): 595-622. 
18. Lemos, S. and Portes, J. (2008). New Labor? The Impact of Migration from Central and Eastern European Countries on the UK Labor Market. IZA Discussion Paper No. 3756.

19. Lewin-Epstein, N.; Semyonov, M.; Kogan, I.; Wanner, R. A. (2003). Institutional Structure and Immigrant Integration: A Comparative Study of Immigrants' Labor Market Attainment in Canada and Israel. International Migration Review, 37 (2): 389-420.

20. Longhi, S.; Nijkamp, P. and Poot, J. (2005). A Meta-Analytic Assessment of the Impact of Immigration on Wages. Journal of Economic Surveys, 19 (3): 451-477.

21. Massey, D. S. and Brown, A. E. (2011). Movement between Mexico and Canada: Analysis of a New Migration Stream. Migraciones Internacionales, 6, 188 (1): 163-188.

22. Lucas, R. E. B. and Stark, O. (1985). Motivations to remit: Evidence from Botswana. Journal of Political Economy, 93 (5): 901-918.

23. Kowalski, T. and Polowczyk, J. (2012). Comparative Analysis of Economic Transformation in the Ukraine and Selected European Countries. WP 8 (1), Poznan: University of Economics.

24. Lupták, M. (2008)."Push” faktory pracovní migrace do zahraničí z území dnešní Ukrajiny, in: Drbohlav, D. (ed.). Nelegálni ekonomické aktivity migrantů (Česko v europském kontextu). Praha: Karolinum.

25. Malynovska, O. (2008). Migrace z Ukrajiny (s důrazem na Česko jako cílovou zemi), in: Drbohlav, D. (ed.). Nelegální ekonomické aktivity migrantĩ (Česko v evropském kontextu). Praha: Karolinum: 212-221.

26. Massey, D. S.; Durand J. and Pren, K. A. (2011). Migardollars in America: A Comparative Analysis. Paper presented at International Conference "The Migration-Development Nexus Revisited: State of the Art and Ways Ahead", University of Trento, June.

27. Massey, D. S. and Connor, P. (2010). Economic Outcomes among Latino Migrants to Spain and the United States: Differences by Source Region and Legal Status. International Migration Review, 44 (4): 802-829.

28. Model, S. and Ladipo, D. (1996). Context and opportunity: minorities in London and New York. Social Forces, 75 (2): 485-510.

29. Näre, L. (2003).Ukrainian and Polish Domestic Workers in Naples: A Case of East-South Migration. http://www.migrationonline.cz.

30. Ratha, D. (2005). Workers' Remittances: An Important and Stable Source of External Development Finance. Economics Seminar Series, paper 9.

31. Scrinzi, F. (2008). Migrations and the restructuring of the welfare state in Italy: Change and continuity in the domestic work sector, in: H. Lutz (ed.). Migration and Domestic Work: A European Perspective on a Global Theme. Aldershot: Ashgate: 29-42.

32. Siar, S. (2008). Migration in Ukraine: A Country Profile. Geneva: International Organization for Migration.

33. Signorelli, M.; Choudhry, M. and Marelli, E. (2012). The Impact of Financial Crises on Female Labour. The European Journal of Development Research, 24: 413-433.

34. Solari, C. (2006). Professionals and saints: How immigrant careworkers negotiate gender identities at work. Gender and Society, 20 (3): 301-331. 
35. Sjaastad, L. A. (1962). The costs and returns of human migration. The journal of political economy, 70 (5): 80-93.

36. Stark, O. (1978). Economic-Demographic Interaction in the Course of Agricultural Development: The Case of Rural-to-Urban Migration. New York: United Nations, Food and Agriculture Organization.

37. Stojanov, R.; Strielkowski, W. and Drbohlav, D. (2011). Labour Migration and Remittances: Current Trends in Times of Economic Recession. Geografie, 116 (4): 375-400.

38. Šarović, R. (2012). Migration of Farmers in Montenegro (1948.-2011). Sociologija i prostor, 194 (3): 379-393.

39. Šlezak, H. (2013). The Role of the Roma in the Demographic Resources of Međimurje County. Sociologija i prostor, 195 (1): 21-43.

40. Todaro, M. P. (1969). A Model of Labour Migration and Urban Unemployment in Less Developed Countries. American Economic Review, 59(1): 138-148.

41. Tsegai, D. (2007). Migration as a Household Decision: What are the Roles of Income Differences? Insights from the Volta Basin of Ghana. The European Journal of Development Research, 19: 305-326.

42. Vargas-Silva, C. (2011). Remittances and Development: Recent evidence in the times of financial turbulence. Oxford: University of Oxford.

43. Vianello, F. (2008). The Italian side of Ukrainian migration: The social networks role, in: Metodologja, Teorija ta Praktika sociologičnogo analizu sučasnogo suspil'stva: Zbirnik Naukovich Praz, vol. 2. Charkiv: Charkivskii Nazionalnii Universitet Imeni B. N. Karazina.

44. Vianello, F. (2009). Suspended migrants: Return migration to the Ukraine, Paper presented at Social Inequalities and Migration in Post-Communist Societies conference, Poznań. Poland 21-22 September 2009.

45. Tahal, R. (2013). Efektivita sběru dat u kvantitativních marketingových výzkumů”. Marketing \& Komunikace, 23 (4): 4-5.

46. World Bank (2007). 10 Years after the Crisis. Special Focus: Sustainable development in East Asia's Urban Fringe. East Asia and Pacific Update. Washington: The World Bank, East Asia and Pacific Region. April.

47. Zimmermann, K. F. and Winter-Ebmer, R. (1998). East-West Trade and Migration: The Austro-German Case. IZA Discussion Paper No. 2, Bonn: IZA. 
Elena Ambrosetti

Universita Roma Sapienza, Ekonomski fakultet, Odjel MEMOTEF, Rim, Italija

Eralba Cela

Universita Politechnica delle Marche, Odjel za ekonomiju, Ancona, Italija

Wadim Strielkowski* *

Ekonomski fakultet, Fakultet međunarodnih odnosa, Odjel za turizam, Prag, Čěka Republika e-mail:wadim.strielkowski@vse.cz

Josef $\boldsymbol{A}$ brhám

Ekonomski fakultet, Fakultet međunarodnih odnosa, Odjel za turizam, Prag, Češka Republika

\section{Ukrajinski migranti u Europskoj uniji: komparativna studija Češke Republike i Italije}

\section{Sažetak}

Članak donosi komparativnu analizu povezanosti osobnih karakteristika migranata i njihova ponašanja pri transferu financijskih sredstava u domovinu. Također ispituje odrednice integracije i potvrđuje hipotezu o prestanku transfera novca ukrajinskih migranata iz Češke Republike i Italije. Naše istraživanje pokušava odgovoriti na brojna nova pitanja utvrđujući postoje li neke posebne značajke ukrajinskih migranata u EU i njihovih obitelji u Ukrajini. Rezultati pokazuju da su migracijske karakteristike etničke grupe ili nacije iste, bez obzira na zemlju migracije. Ponašanje ukrajinskih migranata u Češkoj i Italiji u vezi s transferom novca u domovinu značajno određuje njihova financijska situacija, demografska obilježja, stupanj radnog znanja i vještina te stupanj integracije u novu zemlju kao i specifičnost društvenog konteksta. Štoviše, postoje dokazi da ukrajinski migranti koji su bolje uklopljeni u novu zemlju upućuju manje novčanih transfera u domovinu ili to uopće ne čine.

Ključne riječi: internacionalna migracija, tržište rada, Češka Republika, Ukrajina, novčani transferi. 